\title{
CHANGES IN QUALITY CHARACTERISTICS OF LACOUM WITH CORNEL PUREE DURING STORAGE
}

\author{
L. Gordienko, V. Tolstikh, L. Pojitkova \\ Odessa national academy of food technologies
}

\begin{tabular}{l} 
Key words: \\
Oriental sweets \\
The lacoum \\
The cornel puree \\
Pastille products \\
The storage \\
Moisture content \\
The density \\
Durability \\
Packaging materials \\
\hline
\end{tabular}

Article history:

Received 08.05.2018

Received in revised form

23.05.2018

Accepted 07.06.2018

Corresponding author:

V. Tolstikh

E-mail:

tolstihvu@gmail.com

\begin{abstract}
Modern ideas about the healthy eating require the search of new decisions when developing technologies and expansion the range of high-quality confectionery with high nutritional and biological value. Pastille products have special jelly structure, that appears due to ability of pectin substances that are part of fruit and berry raw materials, to form jelly structure of necessary durability at certain terms. The use of fruit semi-finished products also allows confectionery to taste as natural fruit and berries, to enrich them with vitamins and minerals. The cornel puree belongs to the raw material ingredients with high content of biologically active substances.

The influence of different types of packaging materials and the cornel puree on sensory, physical, chemical as well as the rheological characteristics of the lacoum quality during its storage is shown in the paper. During the storage of the lacoum process of drying is characteristic, when a loss of primary consistency, change of structure and form of products take place. The positive effect of cornel puree was determined, obtained results show that it leads to the decreasing of density, and at the same time, to increasing of the spatial structure durability of product. In the lacoum with the cornel puree, that was kept in the packages from metalized polypropylene, the change of rheological properties took place considerably slower than in other products, it had resiliently-elastic consistency.

An expert assessment of the lacoum quality has been carried out in the end of expiration date. Using packaging materials, which were made from metalized polypropylene, permits to save range of quality characteristics up to 2 months from production date, according to the national standard.
\end{abstract}

DOI: $10.24263 / 2225-2924-2018-24-3-20$ 


\title{
ЗМІНА ПОКАЗНИКІВ ЯКОСТІ ЛУКУМУ ЗБИВНОГО НА ОСНОВІ КИЗИЛОВОГО ПЮРЕ ПРИ ЗБЕРІГАННІ
}

\author{
Л.В. Гордіснко, В.Ю. Толстих, Л.Г. Пожиткова \\ Одеська начіональна академія харчових технологій
}

Сучасні уявлення про здорове харчування вимагають пошуку нових рішень при розробленні технологій $і$ розширенні асортименту кондитерських виробів покращеної якості з підвищеною харчовою та біологічною иінністю. Пастильні вироби мають особливу драглеподібну структуру, яка виникає завдяки здатності пектинових речовин, що входять до складу плодовоягідної сировини, при певних умовах утворювати драглі необхідної міцності. Використання плодово-ягідних напівфабрикатів дає змогу також надавати збивним кондитерським виробам смак натуральних плодів та ягід, збагачувати їх вітамінами й мінеральними речовинами. До сировинних інгредієнтів з підвищеним вмістом біологічно активних речовин відноситься пюре з плодів кизилу.

У статті визначено вплив кизилового пюре та різних видів пакувальних матеріалів на зміну органолептичних, фізико-хімічних $і$ структурно-механічних показників лукуму збивного у процесі його зберігання. При зберіганні лукуму характерним є проиес висихання, коли відбувається втрата первинної консистениії, зміна структури і форми виробів. Комплекс проведених досліджень показав, щу використання кизилового пюре приводить до уповільнення процесу висихання $i$, як наслідок, менш інтенсивного зниження густини та підвищення міцності просторової структури виробів. У лукуму на основі кизилового пюре, що зберігався у металізованих поліпропіленових пакетах, зміна структурно-механічних властивостей відбувалась значно повільніше, ніж в інших виробів, при иьому він зберігав ніжну, пружно-еластичну консистенцію.

Якість лукуму збивного наприкінці його зберігання оцінювали за мікробіологічними й органолептичними показниками. Використання як пакувальних матеріалів пакетів з металізованого поліпропілену надає можливість зберегти показники якості в межах, передбачених стандартом, протягом двох місяиів.

Ключові слова: східні солодощі, лукум збивний, пюре з кизилу, пастильні вироби, зберігання, вологість, густина, міцність, пакувальні матеріали.

Постановка проблеми та аналіз останніх досліджень і публікацій. Пріоритетним напрямом розвитку кондитерської промисловості України $\epsilon$ створення кондитерських виробів зі зниженою калорійністю, підвищеним вмістом біологічно-активних речовин, лікувально-профілактичних виробів $\mathrm{i}$ продуктів для дитячого харчування, що містять функціонально-фізіологічні інгредієнти. Серед великого асортименту кондитерських виробів група східних солодощів користується постійно зростаючим попитом у споживачів і відрізняється різноманітним складом, оригінальними смаковими якостями, 
високою харчовою цінністю та використанням натуральних рецептурних компонентів. Одним з найбільш популярних видів східних солодощів $\epsilon$ лукум збивний. Він відноситься до пастильних виробів піноподібної структури, що містять у своєму складі білок і пектинові речовини як структуроутворювач, які $є$ корисними функціональними інгредієнтами. Ці ласощі не містять жирів, ïx можна віднести до низькокалорійних продуктів, так званих «легких» солодощів, і рекомендувати для вживання маленьким дітям, а також людям, які піклуються про своє здоров'я [1].

Сучасні уявлення про здорове харчування вимагають від дослідників пошуку нових рішень при розробленні технологій і розширенні асортименту пастильних кондитерських виробів покращеної якості зі зниженою калорійністю, лікувально-профілактичними властивостями. На сьогодні актуальним $\epsilon$ використання натуральних підсолоджувачів (екстракт стевії, фруктоза, ізомальтулоза тощо) та йодовмісних добавок для профілактики йододефіциту, ожиріння та цукрового діабету [2-4]. Так, з метою збагачення нових пастильних виробів оздоровчого призначення йодом і комплексом мінеральних речовин запропоновано використовувати концентрат еламіну та дієтичну добавку Ламідан із вмістом органічно зв'язаних йоду та селену, необхідних для синтезу гормонів щитовидної залози. Завдяки наявності у складі біологічно-активної добавки Ламідан альгінових кислот, вона використовується не лише як натуральний ентеросорбент, а також як ефективний стабілізатор піноподібних мас [5].

У кондитерській промисловості при виробництві пастильних виробів застосовуються піноутворювачі, які формують піноподібну структуру готової продукції та покращують іiі органолептичні показники. На процес піноутворення зефірних мас впливають продукти біомодифікації зернової сировини (вівса і ячменю). Їх використання дає змогу не тільки підвищити якість і розширити асортимент виробів, але й раціонально використовувати високовартісну сировину: пектин, цукор-пісок та яєчний білок. При цьому відбувається сповільнення процесу висихання виробів за рахунок більш міцного зв'язування вологи полісахаридами добавки й утримання іiі в цьому стані протягом усього періоду зберігання [6].

Як цінну сировину для виробництва кондитерських виробів дієтичного спрямування використовуються продукти переробки топінамбуру (порошок, пюре, паста). Застосування добавок, що містять значну кількість інуліну, в комплексі з рослинними білками, вітамінами і мікроелементами в рецептурах збивних виробів та м'яких цукерок дає змогу отримати продукти 3 лікувально-профілактичними властивостями, підвищеною харчовою і біологічною цінністю $[7 ; 8]$.

Перспективним напрямом розширення асортименту, підвищення харчової та біологічної цінності пастильних виробів піноподібної структури $є$ використання місцевої плодово-ягідної сировини. Збивні вироби мають особливу драглеподібну структуру, яка виникає завдяки здатності пектинових речовин, що входять до складу цієї сировини, при певних умовах утворювати драглі необхідної міцності. Однак призначення плодово-ягідних напівфабрикатів 
визначається не тільки як пектинвмісної сировини, але й продуктів, що надають збивним виробам смак натуральних плодів та ягід, збагачують вироби вітамінами й мінеральними речовинами. Порівняно низькі температурні режими та помірний механічний вплив при виробництві пастильних виробів надають можливість вводити нетрадиційну сировину без погіршення смакових показників і максимально зберігати корисні властивості.

Для збагачення лукуму збивного біологічно-активними речовинами та надання йому функціональних властивостей використовуються порошки 3 плодів і м'якоті дикорослої шипшини [9]. Внесення порошків шипшини призводить до незначного зниження піноутворюючої здатності лукумних мас та ущільнення їх структури, що несуттєво впливає на якість готових виробів. Під час зберігання лукуму збивного відбувається сповільнення процесу висихання за рахунок адсорбційних властивостей порошків.

На основі попередніх досліджень розроблено рецептуру лукуму збивного «Кизиловий» із заміною 50\% яблучного пюре нетрадиційним для пастильних виробів кизиловим пюре. Одержані вироби мали ніжну консистенцію 3 дрібнодисперсною структурою та приємним кисло-солодким смаком і ароматом кизилу [10].

При зберіганні лукуму збивного характерним є процес висихання, коли відбувається втрата первинної консистенції, зміна структури і форми. На характер та інтенсивність процесів, перебіг яких відбувається під час зберігання виробів, суттєво впливають як умови їх зберігання, так і рецептурний склад, природа та концентрація драглеутворюючих речовин, ступінь дисперсності збивних мас і технологічні параметри їх виробництва.

Метою дослідження $\epsilon$ визначення впливу кизилового пюре та різних видів пакувальних матеріалів на зміну органолептичних, фізико-хімічних i структурно-механічних показників якості лукуму збивного у процесі його зберігання.

Результати і обговорення. При проведенні досліджень розроблені зразки лукуму з кизиловим пюре зберігали у картонних коробках, загорнутих у поліетилен, і в пакетах з металізованого поліпропілену впродовж 60 діб. Контроль зберігали у картонному пакуванні при параметрах, передбачених нормативною документацією.

Висихання як найважливіший процес при зберіганні піноподібних виробів $€$ наслідком втрати ними значної частини вологи з поверхні внаслідок переміщення іiї з центральних шарів до периферійних. Це явище викликає пересичення рідкої фази та іï перекристалізацію, внаслідок чого збільшується частка твердої фази. Нові кристали нарощуються на вже існуючі. За рахунок збільшення розмірів кристалів структура збивної маси стає грубодисперсною. Вироби стають твердими і втрачають ніжну консистенцію $[11 ; 12]$.

Встановлено уповільнення процесу висихання при зберіганні лукуму збивного з кизиловим пюре порівняно 3 контрольним зразком (рис. 1). Наявність твердих часточок цього пюре у складі піни, ймовірно, призводить до зменшення втрати вологи внаслідок звуження каналів піни, за рахунок підвищення шорсткості її стінок і утворення локальних «заторів» 3 частками, які не прилипли до бульбашок. 


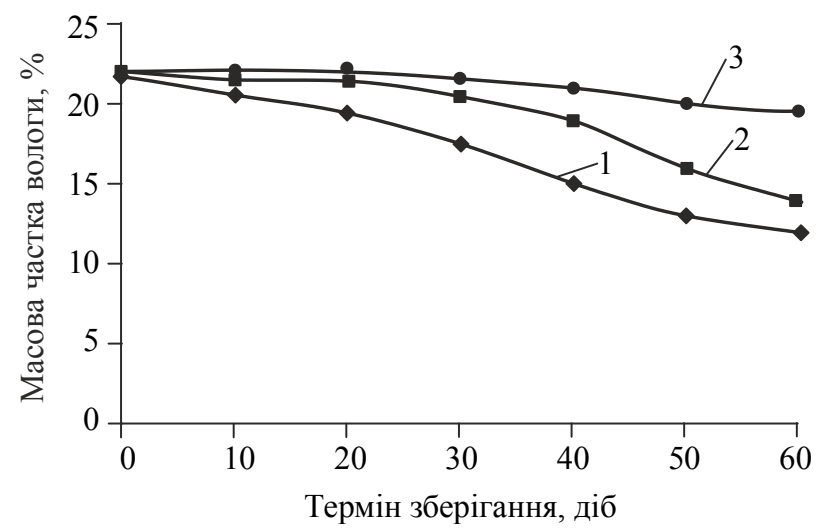

Рис. 1. Зміна масової частки вологи лукуму при зберіганні: 1 - контроль; 3 кизиловим пюре: 2 - у картонних коробках, 3 - у пакетах з металізованого пропілену

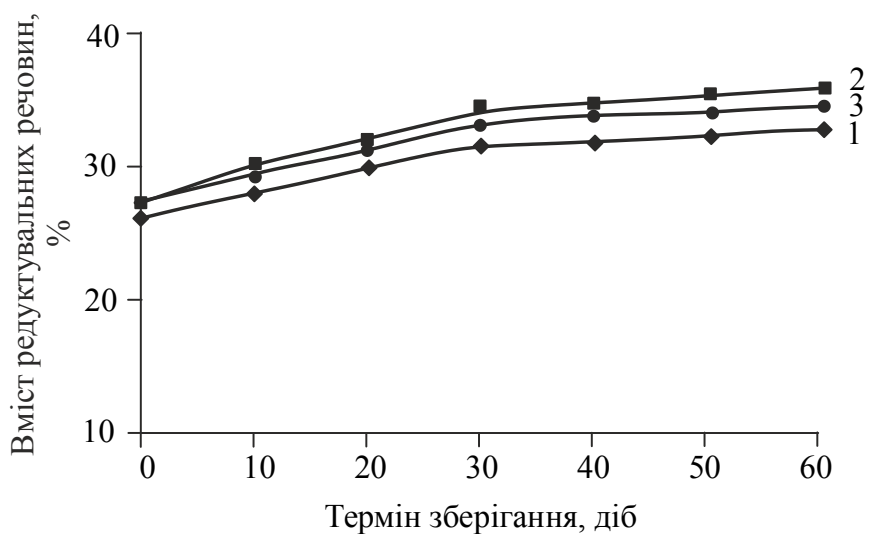

Рис. 2. Зміна вмісту редукувальних речовин лукуму при зберіганні:

1 - контроль; 3 кизиловим пюре: 2 - у картонних коробках, 3 - у пакетах з металізованого пропілену

Відповідно до ДСТУ 4688:2006 термін зберігання лукуму збивного становить 25 діб, масова частка вологи $22 \pm 2 \%$. Вологість контрольного зразка знаходиться у межах норми протягом 20 діб, тоді як для лукуму з кизиловим пюре, що зберігався у картонних коробках, протягом 35 діб, а в пакетах 3 металізованого поліпропілену — протягом 60 діб. Тож застосування пакетів 3 металізованого поліпропілену дає змогу уповільнити процес висихання виробів і зберігати показники їх якості в межах, передбачених стандартом, протягом двох місяців.

У процесі зберігання лукуму накопичуються редукувальні речовини (РР) внаслідок хімічних змін. Ці процеси більшою мірою залежать від температури зберігання й тривалості ії впливу. При недотриманні умов зберігання вироби будуть мати грубу поверхню, підвищену липкість, порушення структури. Зі збільшенням терміну зберігання вміст РР в усіх дослідних зразках 
підвищується незначно, в межах допустимої норми (рис. 2). Так, для контрольного зразка через 30 діб зберігання вміст РР збільшився на 5,2\%, для лукуму з кизиловим пюре, що зберігався у картонних коробках, — на 6,8\%, а у пакетах з металізованого поліпропілену - на 5,9\%.

Стабільність та зміни структури лукуму в процесі зберігання безпосередньо обумовлені фізико-хімічними, біохімічними, колоїдно-хімічними процесами, які призводять до зміни первинних структурно-механічних властивостей [11; 12].

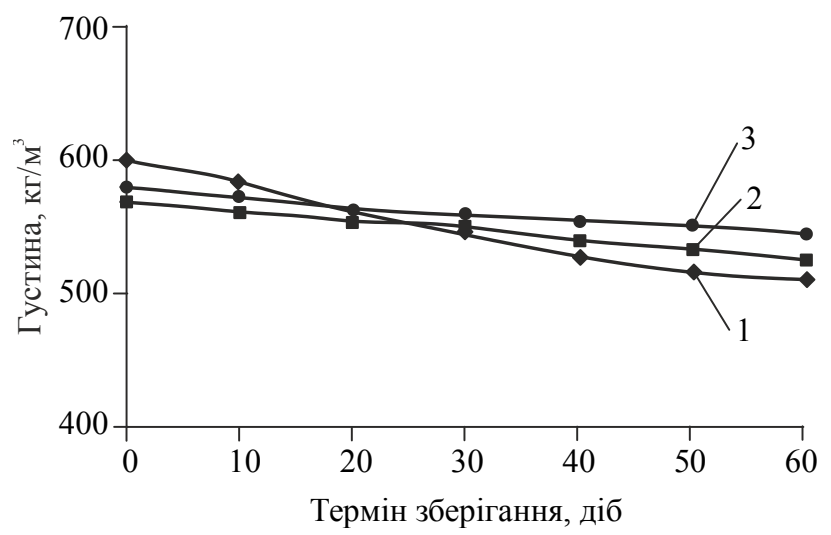

Рис. 3. Зміна густини лукуму при зберіганні:

1 - контроль; $з$ кизиловим пюре: 2 - у картонних коробках, 3 - у пакетах з металізованого пропілену

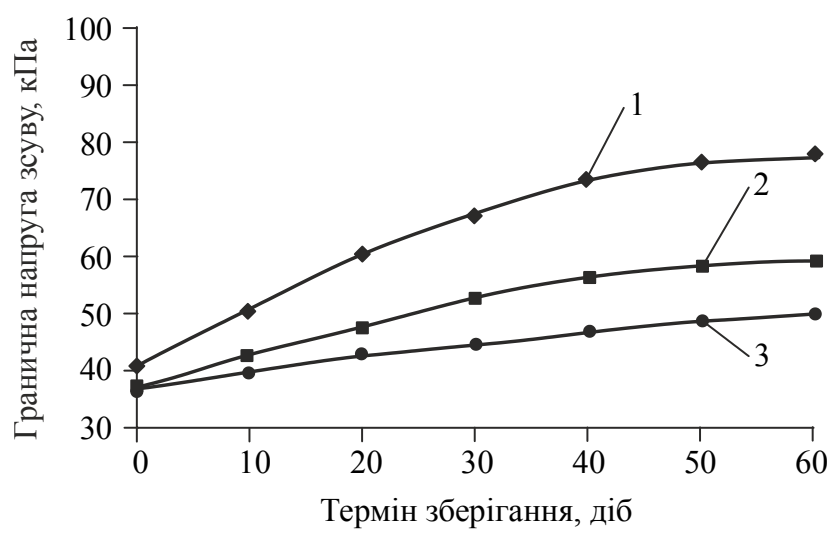

Рис. 4. Зміна граничної напруги зсуву лукуму при зберіганні:

1 - контроль; 3 кизиловим пюре: 2 - у картонних коробках, 3 - у пакетах з металізованого пропілену

Встановлено, що при зберіганні впродовж 2 місяців для всіх зразків спостерігається зменшення густини (рис. 3). Для контрольного зразка характерне більш інтенсивне постійне зниження густини з 600 до 510 кг/м ${ }^{3}$, що пояснюється втратою вологи виробів у результаті висихання. Зразки 3 додаванням кизилового пюре не так інтенсивно втрачають початкову об'ємну масу. Так, зразок, що зберігався в пакетах з металізованого поліпропілену, через 2 міся- 
ці має таку ж густину як контрольний, який зберігали 1 місяць. Ймовірно, це відбувається за рахунок більш міцно зв'язаної вологи, в результаті зменшення швидкості течії вологи по каналах піни та підвищення гальмуючої дії поверхневих шарів плівки з внесенням кизилового пюре.

Аналіз результатів визначення міцності просторової структури лукуму збивного за зміною граничної напруги зсуву показав, що в контрольному $\mathrm{i}$ дослідних зразках відбувається ущільнення структури. Це зумовлено тим, що дисперсне середовище піноподібної структури лукуму утворює стійкий каркас, гранична напруга зсуву якого зростає впродовж зберігання (рис. 4). У лукуму на основі кизилового пюре, що зберігався в металізованих поліпропіленових пакетах, зміна структурно-механічних властивостей відбувалась значно повільніше, ніж в інших виробів, при цьому він зберігав ніжну, пружно-еластичну консистенцію. Так, упродовж 60 діб зберігання гранична напруга зсуву даного зразка зросла на 13,8 кПа, зразка у картонних коробках на 23,5 кПа, тоді як у контрольного зразка - на 36,4 кПа. Він мав суху, тверду консистенцію, що не відповідала вимогам до якості виробів.

Якість лукуму збивного на основі кизилового пюре оцінювали наприкінці зберігання у різних видах пакувальних матеріалів за мікробіологічними i органолептичними показниками. Дослідження мікробіологічних характеристик за кількістю МАФАМ, дріжджів і пліснявих грибів показало, що при зберіганні лукуму в пакетах з металізованого поліпропілену протягом двох місяців ці показники знаходились у допустимих межах.

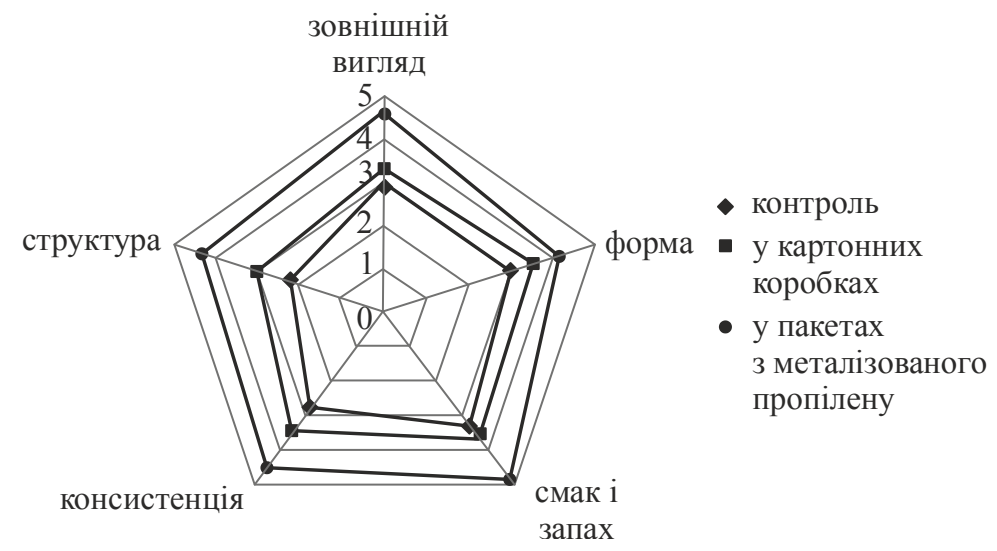

Рис. 5. Профілограма органолептичної оцінки лукуму збивного з кизиловим пюре при зберіганні

Органолептичну оцінку дослідних зразків лукуму проводили за допомогою бальної шкали за такими показниками: зовнішній вигляд, форма, смак і запах, консистенція та структура (рис. 5). У результаті проведеної експертної оцінки встановлено, що зразки 3 кизиловим пюре, які зберігались у пакетах 3 металізованого поліпропілену, мали найкращу якість: гарний зовнішній вигляд, приємний кисло-солодкий смак, ніжну, пружну консистенцію, дрібнодисперсну структуру. 


\section{Висновки}

Отже, комплекс проведених досліджень зміни показників якості лукуму збивного при зберіганні показав, що використання кизилового пюре приводить до уповільнення процесу висихання i, як наслідок, менш інтенсивного зниження густини та підвищення міцності просторової структури виробів. Використання як пакувальних матеріалів пакетів 3 металізованого поліпропілену дає змогу зберегти показники якості в межах, передбачених стандартом, протягом двох місяців.

\section{Лiтература}

1. Иоргачева Е.Г. Перспективы производства низкосахаристых восточных сладостей на рынке Украины / Е.Г. Иоргачева, Л.В. Гордиенко, В.Ю. Толстых, К.В. Аветисян // Пищевая наука и технология. - 2012. — № 1. - С. 3-5.

2. Sherine N. Production and physicochemical assessment of new stevia amino acid sweeteners from the natural stevioside [Text] / N. Sherine, Khattab I.Mona, Massoud Yahya El-Sayed Jad, Adnan A. Bakhit, Ayman El-Faham // Food Chemistry. — 2015. — Vol.173. P. $979-985$.

3. Соколовська О.О. Исследование профилактического влияния и безопасности разработанных видов пастильных изделий с использованием нетрадиционного сырья / О.О. Соколовська, Г.И. Дюкарева // Вісник НТУ «ХПІ». — 2016. — № 17. — С. 101-104.

4. Красина И.Б. Исследование реологических свойств жевательных конфет на изомальтулозе / И.Б. Красина, А.Н. Куракина, З.А. Баранова // Харчова наука і технологія. 2014. - № 1. - С. $34-38$.

5. Шаповалова Н.П. Вплив рецептурних компонентів на показники якості пастильних виробів з Ламіданом і цикорлактом / Н.П. Шаповалова // Вісник ЛІЕТ: збірник наукових праць. — 2013. - С. 197-200.

6. Румянцева В.В. Применение нетрадиционного сырья при производстве пастильных масс / В.В. Румянцева, Н.М. Ковач, А.Ю. Гурова // Известия ВУЗов. Пищевая технология. 2010. - № 4. - C. 10-12.

7. Пат. 2130273 РФ, А 23 L1/052. Способ производства кондитерских изделий с лечебно-профилактическими свойствами с использованием топинамбура [Текст] / Зеленков В.Н.; заявитель и патентообладатель Зеленков Валерий Николаевич, № 96122320/13; заявл. 20.11.1996; опубл. 20.05.1999. — 4 с.

8. Лобосова Л.А. Функциональные кондитерские изделия с нетрадиционным сырьем / Л.А. Лобосова, Т.Н. Малютина, М.Г. Магомедов, И.Г. Барсукова // Современная наука: актуальные проблемы и пути их решения. - 2013. - № 3. - С. 25-26.

9. Негматуллоева Р.Н. Использование порошков из плодов шиповника в производстве збивного лукума / Р.Н. Негматуллоева, В.А. Васькина, Г.Н. Дубцова // Кондитерское и хлебопекарное производство. - 2011. - № 41. - С. 30-32.

10. Иоргачева Е.Г. Использование кизилового пюре в производстве лукума сбивного / Е.Г. Иоргачева, Л.В. Гордиенко, В.Ю. Толстых, К.В. Аветисян // Зб. Наук. Пр. ОНАХТ. Одеса, 2013. - Вип. 43. - Т. 1. - С. 187-190.

11. Зубченко A.B. Физико-химические основы технологии кондитерских изделий: Учебник. - 2-е изд., перераб. и доп. / Воронеж. гос. технол. акад. — Воронеж, 2001. $389 \mathrm{c}$.

12. Урьев Н.Б. Пищевые дисперсные системы. Физико-химические основы интенсификации технологических процессов / Н.Б. Урьев, М.А. Талейсник. - Москва : Агропромиздат, $1985 .-296 \mathrm{c}$. 